\title{
A sequential sampling technique for female adult mites of Varroa jacobsoni Oudemans in the sealed worker brood of Apis mellifera ligustica Spin
}

\author{
I Floris \\ Istituto di Entomologia agraria, Università degli Studi di Sassari, \\ Via E De Nicola, ()7 I00 Sassari, Italy
}

(Received 3 June 1996; accepted 20 February 1997)

\begin{abstract}
Summary - A method of sequential sampling for estimating the female adult mite population of Varroa jacobsoni in the sealed worker brood of Apis mellifera ligustica Spin, in relation to two hypothetical critical densities $(0.05$ and 0.1 female adult mite per cell) is proposed. Iwao's patchiness regression method, based on the mean crowding - mean relationship, was used to analyze spatial distribution of the mite and to define a sequential graph or table.
\end{abstract}

Varroa jacobsoni / dispersion index / spatial distribution / sequential sampling / sealed worker brood / Apis mellifera ligustica Spin

\section{INTRODUCTION}

Practical methods of measuring the Varroat infestation in the brood are essential to achieve satisfactory control of the varroosis (for example by supervised control) and to verify in the field, for practical purposes, the approximate efficacy of the treatment. This is particularly needed in the Mediterranean areas, where sealed worker broods are usually present in honeybee colonies.

Until recently, literature on the quantitative evaluation of Varroa populations, with- out using acaricide treatments or sacrificing the colony (Milani. 1993), was limited. Its evaluation was generally based on the examination of ca 400 cells per colony containing worker pupae, according to a standardized method adopted in field trials (Ferrer-Dufol et al, 1995). The above-mentioned method, however, does not take into account the aggregate mite distribution in the brood (Fuchs, 1988: Floris, 1991, 1992) and may give incorrect estimates if sampling is based on examining only one portion of brood comb per hive.

Tel: (39) 792292 45; fax: (39) 79229329 ; e-mail: a.sattal@ircoba.ss.cnr.it 
The sequential sampling design, which involves a preliminary study to establish the type of distribution, consists in the consecutive examination of the samples (sealed worker brood cells) chosen at random (from the brood combs) and in the evaluation of the accumulated number of the pests (female adult mites) found. With this technique, the total number of samples is variable and depends on whether or not the results so far obtained give a definitive answer to the question asked about the frequency of occurrence of an event (abundance of the mite). This type of sampling is of particular value for the assessment of pest density in relation to control measures, applied only when the pest density has reached a certain level (intervention threshold).

By this method, we obtain a sequential table or sequential graph that may be used to assess whether the mite infestation is higher or lower than predefined intervention thresholds and if treatment is necessary or not. Very few samples need to be taken for practical purposes and the expenditure of time and effort is minimal. In application, the sequential sampling can be limited to a small number of hives $(3-5 \%)$ in the apiary to establish the approximate Varroa infestation.

\section{MATERIALS AND METHODS}

An extensive study was previously conducted to establish the Varroa distribution in an infestation of sealed honeybee worker brood (Floris, 1991, 1992). A total of 13510 sealed worker brood cells, from 20 combs taken from the nest center of different hives were inspected during summer and autumn when no drone brood was present. The number of female adult mites per cell was recorded. Although offspring was present in many cells, in the statistical study we have considered only the female adult mites because they are more easily recognized.

The average number of female adult mites per cell $(m)$ and variance $\left(\sigma^{2}\right)$, relating to each comb, were used to calculate dispersion indices by Taylor's (1961) power law and Iwao's (1968) patchiness regression method and to determine sample size requirements for estimating the mean population with fixed levels of precision (Floris, 1991, 1992).

In the present study, a statistical reanalysis of the 1991, 1992 data was made using Iwao's patchiness regression method because it provides a good description of the Varroa distribution. Further, it represents a sequential sampling technique that requires fewer samples to estimate mite infestation compared to the number of samples required by a sequential sampling design based on Taylor's power law.

This method consists in the regression of the mean crowding index $\left(m^{*}\right)$ on the mean $(m)$ (Iwao, 1968, 1975, 1977), according to the following equation:

$$
m^{*}=\alpha+\beta m
$$

where:

$$
m^{*} \approx m+\left[\left(\sigma^{2} / m\right)-1\right]
$$

$\alpha$ is a measure of crowding of the organism, and $\beta$ is related to the pattern in which the organism uses its environment (Southwood, 1978).

The density levels $\left(m_{0}\right)$ of 0.05 and 0.1 female adult mites per cell were adopted as hypothetical critical thresholds to calculate upper and lower limits $\left(T 0_{n}\right)$ of the total number of female adult mite sampled, under specified values of $t$ (eg, 1.64 and 1.96 for $90 \%$ and $95 \%$ confidence probability, respectively). A minimum of 30 samples was used to assure a convenient convergence towards normality:

- upper limit:

$$
T^{\prime} O_{n}=n m_{0}+t \sqrt{ }\left\{n\left[(\alpha+1) m_{0}+(\beta-1) m_{0}{ }^{2}\right]\right\}
$$

- lower limit:

$$
T^{\prime \prime} 0_{n}=n m_{0}-t \vee\left\{n\left[(\alpha+1) m_{0}+(\beta-1) m_{0}^{2}\right]\right\}
$$

$T^{\prime} 0_{n}$ and $T^{\prime \prime} 0_{n}$ can easily be calculated for successive values of $n \geq 30$ (number of sealed worker brood cells inspected).

\section{RESULTS AND DISCUSSION}

Descriptive and statistical parameters of the present study are reported in table I. Only 2284 cells $(16.9 \%)$ of the total inspected (13 510) were infested by one or more (max- 


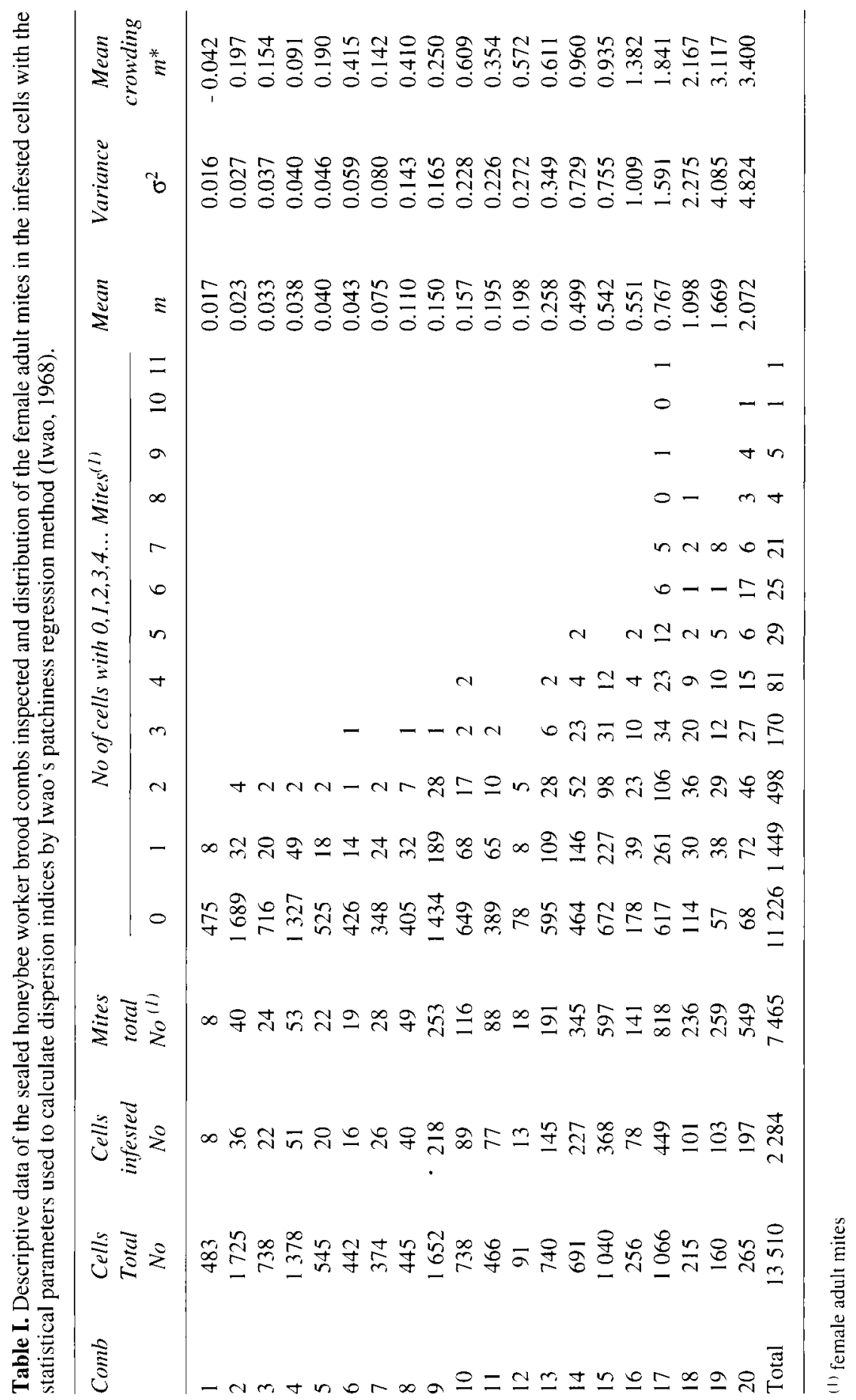


imum 11 adult female) mites. A tolal number of 7465 female adult mites was found. Although many of the infested cells also contained offspring, we considered only adult female mites because they are more easily recognized, particularly as a practical matter.

Iwao's regression provided a consistently good fit for the mite populations $\left(r^{2}=0.969\right)$ (fig 1), showing an aggregated distribution ( $\alpha=0.157$ and $\beta=1.713$ ) (Iwao, 1977). Upper and lower limits (table II) were obtained for the density levels of 0.05 and 0.1 female adult mites per cell, and used to draw a sequential graph (fig 2). In particular, the infestation level of 0.10 was adopted as a prudential intervention threshold because we observed in the field that, at about the 0.15 level, signs of secondary infection were evident in the brood and physical effects were visible on adult bees (wing deformation). In contrast, at levels under 0.05 infestation, no apparent damage was recorded.
In application, using table II or the graph (fig 2), at least 30 sealed worker brood cells chosen at random from nest combs are examined in sequence and sampling is stopped when the accumulated number of female adult mites counted $\left(\mathrm{T}_{0}\right)$ falls outside the range between the upper and lower limits. The sequential graph (fig 2) traces the two sets of curves contemporaneously and may be useful for practical purposes, because it allows the mite population level to be classified in three grades: low ( $m<$ $0.05)$, medium $(0.05 \leq m<0.10)$ and high $(m \geq 0.10)$. If sampling 60 sealed worker brood cells chosen at randon from nest combs produces an accumulated number of female adult mites higher than 6 (zone III) or equal to 0 (zone I), one can conclude that the density of the population under study is equal or higher than 0.10 (high infestation) or lower than 0.05 (low infestation). So, if the infestation level is higher than 0.10 one can decide to carry out the treatment. Whereas, if the accumulated number of mites falls between zero and 6, the popula-

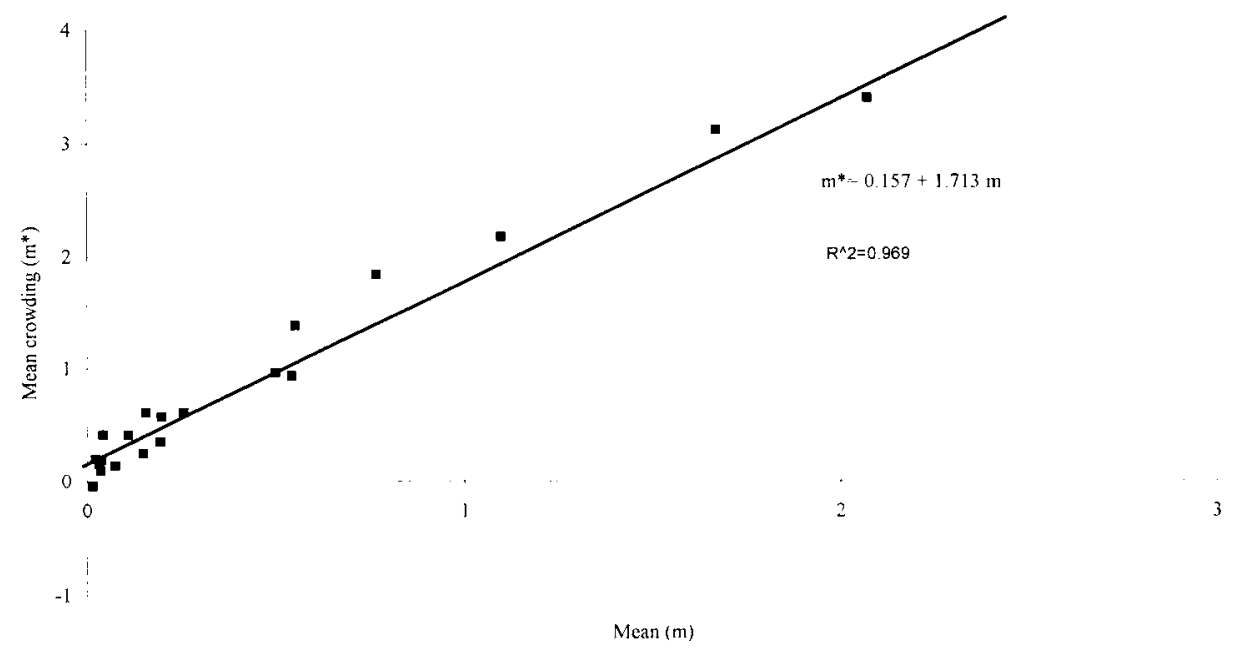

Fig 1. Iwao's patchiness regression for female adult mites of Varroa jacobsoni Oud in sealed worker brood of Apis mellifera ligustica Spin. 


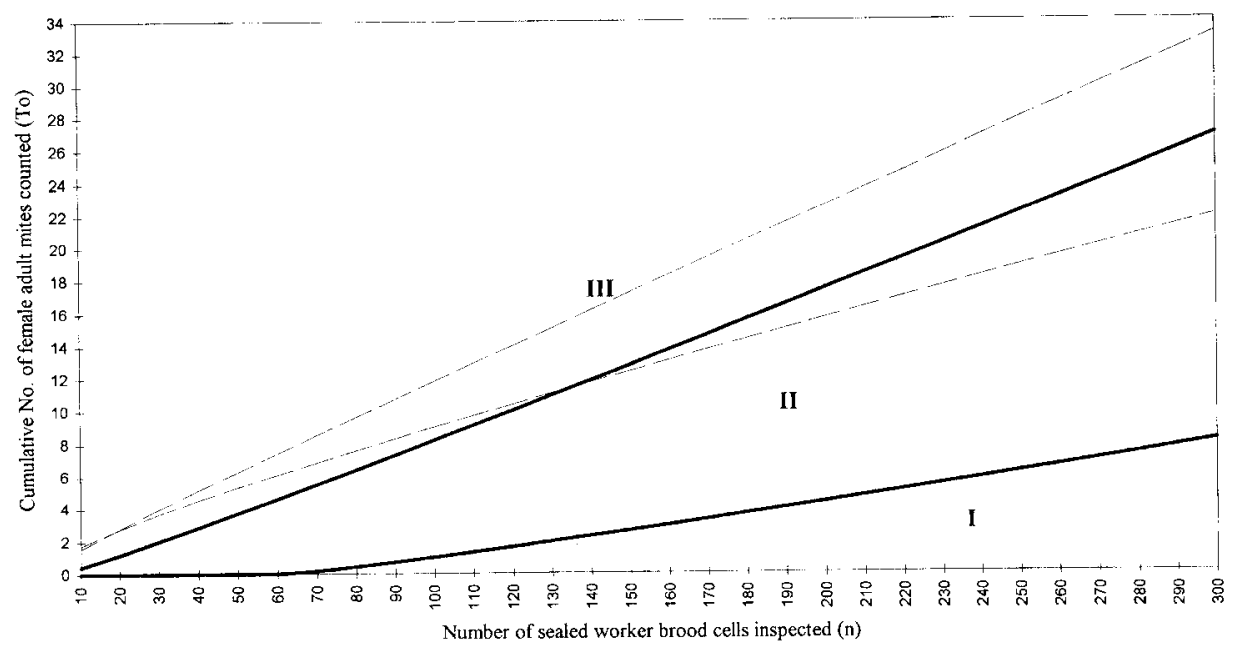

Fig 2. Sequential graph for Varroa jacobsoni in sealed honeybee worker brood for two hypothetical threshold densities of female adult mites per cell $(0.05$ and 0.10$)$, under specified value of $t(1.64$ for $90 \%$ confidence probability). The mite population level can be classified in three grades: low (zone I, $m<0.05$ ), medium (zone II, $0.05 \leq m<0.10$ ), and high (zone III, $m \geq 0.10$ ) densities.

tion level can be classified as between 0.05 and 0.1 female adult mites per cell. In this case, one may continue the sampling inspecting a larger number of cells or repeat it after some weeks. Based on previous studies (Iwao, 1975; Floris, 1991), it is also possible to determine the maximum number of samples to be taken before sampling can be stopped.

Usually, with this technique, very few samples need to be taken and the expenditure of time and effort is minimal. Its application in the field, based on this study, probably should be limited to the summer and autumn, when no drone broods are present.

Additional research is necessary to establish more precisely the population density levels of Varroa jacobsoni associated with extensive damage (intervention thresholds), and to define the relationship between female adult mite infestation in the worker brood and total infestation of the hive.
Résumé - Technique d'échantillonnage séquentiel pour les femelles adultes de l'acarien Varroa jacobsoni Oudemans dans le couvain operculé d'ouvrières d'Apis mellifera ligustica Spin. Nous proposons ici une méthode de classement de la population d'acariens femelles adultes de $V$ jacobsoni en relation avec deux densités critiques choisies $(0,05$ et 0,10 femelle adulte d'acarien par cellule). La méthode de régression de l'agrégativité d'Iwao (Iwao, 1968) a été utilisée pour définir la technique d'échantillonnage séquentiel. Elle consiste en une régression de l'indice moyen de densité $\left(m^{*}\right)$ sur la moyenne $(m)$ selon l'équation suivante : $m^{*}=\alpha+\beta m$, où $m^{*} \approx m+$ $\left[\left(\sigma^{2} / m\right)-1\right] ; \alpha$ est une mesure de la densité de l'organisme et $\beta$ est lié à la façon dont l'organisme utilise son environnement (Southwood, 1978).

L'agrégativité d'Iwao a fourni une bonne corrélation $\left(r^{2}=0,969\right)$ pour la population de 
Table II. Sequential table for Varroa jacobsoni in sealed honeybee worker brood for two hypothetical density levels of female adult mites per cell $\left(m_{0}=0.05\right.$ and $\left.m_{0}=0.10\right)$, under specified value of $t(1.96$ for $95 \%$ confidence probability and 1.64 for $90 \%$ confidence probability).

\begin{tabular}{|c|c|c|c|c|c|c|c|c|}
\hline \multirow{2}{*}{$\begin{array}{l}\text { No of sealed } \\
\text { worker brood } \\
\text { inspected } \\
\text { (n) }\end{array}$} & \multicolumn{2}{|c|}{$\begin{array}{c}\text { Limits for } \\
m_{0}=0.05 \\
t=1.96\end{array}$} & \multicolumn{2}{|c|}{$\begin{array}{c}\text { Limits for } \\
m_{0}=0.10 \\
t=1.96\end{array}$} & \multicolumn{2}{|c|}{$\begin{array}{c}\text { Limits for } \\
m_{0}=0.05 \\
t=1.64\end{array}$} & \multicolumn{2}{|c|}{$\begin{array}{c}\text { Limits for } \\
m_{0}=0.10 \\
t=1.64\end{array}$} \\
\hline & $\begin{array}{l}\text { Upper } \\
\left(T^{\prime} O\right)\end{array}$ & $\begin{array}{l}\text { Lower } \\
\left(T^{\prime \prime} O\right)\end{array}$ & Upper & Lower & Upper & Lower & Upper & Lower \\
\hline 30 & 4.1 & $<0.0$ & 4.2 & 1.8 & 3.7 & $<0.0$ & 4.0 & 2.0 \\
\hline 40 & 5.0 & $<0.0$ & 5.4 & 2.6 & 4.5 & $<0.0$ & 5.1 & 2.8 \\
\hline 50 & 5.9 & $<0.0$ & 6.5 & 3.5 & 5.3 & $<0.0$ & 6.3 & 3.7 \\
\hline 60 & 6.7 & $<0.0$ & 7.7 & 4.3 & 6.1 & $<0.0$ & 7.4 & 4.6 \\
\hline 70 & 7.5 & $<0.0$ & 8.8 & 5.2 & 6.8 & 0.1 & 8.5 & 5.5 \\
\hline 80 & 8.3 & $<0.0$ & 9.9 & 6.1 & 7.6 & 0.4 & 9.6 & 6.4 \\
\hline 90 & 9.0 & $<0.0$ & 11.1 & 6.9 & 8.3 & 0.7 & 10.7 & 7.3 \\
\hline 100 & 9.8 & 0.2 & 12.2 & 7.8 & 9.0 & 1.0 & 11.8 & 8.2 \\
\hline 110 & 10.5 & 0.5 & 13.3 & 8.7 & 9.7 & 1.3 & 12.9 & 9.1 \\
\hline 120 & 11.2 & 0.8 & 14.4 & 9.6 & 10.4 & 1.6 & 14.0 & 10.0 \\
\hline 130 & 12.0 & 1.0 & 15.5 & 10.5 & 11.1 & 1.9 & 15.1 & 10.9 \\
\hline 140 & 12.7 & 1.3 & 16.6 & 11.4 & 11.7 & 2.3 & 16.1 & 11.8 \\
\hline 150 & 13.4 & 1.6 & 17.7 & 12.3 & 12.4 & 2.6 & 17.2 & 12.8 \\
\hline 160 & 14.0 & 1.9 & 18.7 & 13.2 & 13.1 & 2.9 & 18.3 & 13.7 \\
\hline 170 & 14.7 & 2.3 & 19.8 & 14.1 & 13.7 & 3.3 & 19.4 & 14.6 \\
\hline 180 & 15.4 & 2.6 & 20.9 & 15.1 & 14.4 & 3.6 & 20.4 & 15.6 \\
\hline 190 & 16.1 & 2.9 & 22.0 & 16.0 & 15.0 & 4.0 & 21.5 & 16.5 \\
\hline 200 & 16.8 & 3.2 & 23.1 & 16.9 & 15.7 & 4.3 & 22.6 & 17.4 \\
\hline 210 & 17.4 & 3.6 & 24.1 & 17.8 & 16.3 & 4.7 & 23.6 & 18.4 \\
\hline 220 & 18.1 & 3.9 & 25.2 & 18.8 & 16.9 & 5.1 & 24.7 & 19.3 \\
\hline 230 & 18.8 & 4.2 & 26.3 & 19.7 & 17.6 & 5.4 & 25.8 & 20.2 \\
\hline 240 & 19.4 & 4.6 & 27.4 & 20.6 & 18.2 & 5.8 & 26.8 & 21.2 \\
\hline 250 & 20.1 & 4.9 & 28.4 & 21.6 & 18.8 & 6.2 & 27.8 & 22.1 \\
\hline 260 & 20.7 & 5.3 & 29.5 & 22.5 & 19.5 & 6.5 & 28.9 & 23.1 \\
\hline 270 & 21.4 & 5.6 & 30.6 & 23.4 & 20.1 & 6.9 & 30.0 & 24.0 \\
\hline 280 & 22.0 & 6.0 & 31.6 & 24.4 & 20.7 & 7.3 & 31.0 & 25.0 \\
\hline 290 & 22.6 & 6.3 & 32.7 & 25.3 & 21.3 & 7.7 & 32.1 & 25.9 \\
\hline 300 & 23.2 & 6.7 & 33.8 & 26.2 & 21.9 & 8.1 & 33.1 & 26.8 \\
\hline
\end{tabular}

grand nombre de cellules ou en le répétant quelques semaines plus tard.

En général, cette technique ne nécessite qu'un nombre d'échantillons réduit et la dépense en temps et en argent est minime. Néanmoins, des études complémentaires sont nécessaires pour établir des niveaux de densité de varroas plus précis (seuils d'intervention) en association avec les dégâts extensifs causés aux colonies d'abeilles.

Varroa jacobsoni / indice de dispersion / distribution spatiale / échantillonnage 
densité a atteint un certain niveau (seuil d'intervention). Par exemple, si l'échantillonnage de 60 cellules de couvain operculé d'ouvrières choisies au hasard sur les cadres donne un nombre cumulé de femelles adultes supérieur à 6 (tableau II, fig 2), on peut conclure que la densité de la population de varroas est égale ou supérieure à 0,10 et décider d'effectuer un traitement. En revanche, si on ne trouve aucun varroa ou si le nombre cumulé se situe entre 0 et 6 , le niveau de la population peut être classé comme inférieur ou égal à 0,05 ou entre 0,05 et 0,10 femelle/cellule ce qui, de toutes façons, est en dessous du seuil d'intervention prédéfini. Dans ce cas, on peut poursuivre l'échantillonnage en inspectant un plus grand nombre de cellules ou en le répétant quelques semaines plus tard.

En général, cette technique ne nécessite qu'un nombre d'échantillons réduit et la dépense en temps et en argent est minime. Néanmoins, des études complémentaires sont nécessaires pour établir des niveaux de densité de varroas plus précis (seuils d'intervention) en association avec les dégâts extensifs causés aux colonies d'abeilles.

Varroa jacobsoni / indice de dispersion / distribution spatiale / échantillonnage séquentiel / couvain operculé d'ouvrières / Apis mellifera ligustica Spin

\section{Zusammenfassung - Sequentielle Pro- bennahme der adulten weiblichen Mil- ben Varroa jacobsoni Oudemans in der verdeckelten Arbeiterinnenbrut von Apis mellifera ligustica Spin. Zur Einschätzung der Population von adulten weiblichen Var- roa jacobsoni- Milben in der vedeckelten Arbeiterinnenbrut von Apis mellifera ligu- stica Spin bezüglich zweier hypothetischer kritischer Befallsdichten $(0,05$ und 0,1 adul- ten weibliche Milben pro Zelle) wird eine Methode sequentieller Probennahme vor- geschlagen. Zur Festlegung der Methode sequentieller Probennahme wurde die}

Regressionsmethode für geklumpte Verteilungen von Iwao (1968) angewendet. Die Methode beruht auf der Regression des mittleren Dichteindex $\left(m^{*}\right)$ auf das Verteilungsmittel $(m)$ nach folgender Beziehung: $\mathrm{m}^{*}=\alpha+\beta m$ mit $m^{*} \approx m+\left[\left(\sigma^{2} / m\right)-1\right] ;$ hierbei ergibt $\alpha$ einen Masstab der Dichte des Organismus; $\beta$ kennzeichnet das Verteilungsmuster, in dem der Organismus seine Umgebung nutzt (Southwood, 1978).

Iwao's aggregierte Verteilung ergab eine gute Anpassung der Milbenverteilung (Abb 1). Dies bestätigte, daß die Milben nicht gleichmäßig, sondern geklumpt in der Brut verteilt sind. Anhand der erhaltenen oberen und unteren Grenzen für zwei Befallsdichten $(0,05$ bzw 0,1 weibliche Milben pro Zelle) wurde ein sequentieller Graph erstellt (Abb 2), in dem der Milbenbefall in drei Abstufungen niedrig (Zone I, $m<0,05$ ), mittel (Zone II, $0,05 \leq m<0,1$ ) und hoch (Zone III, $m \geq 0,1$ ) eingeteilt wurde. Die sequentielle Tabelle und der sequentielle Graph können zur Abschätzung der Milbendichte für Bekämpfungsmaßnahmen verwendet werden, insbesondere zur Beurteilung der Frage, ob die Befallsdichte einen bestimmten kritischen Level erreicht hat (Interventionsschwelle). Wenn sich beispielsweise bei der Auswertung von 60 auf den Brutwaben zufällig gewählten Zellen eine insgesamt höhere Anzahl als 6 weibliche Varroamilben ergibt, kann daraus auf eine Populationsdichte gleich oder höher als 0,1 geschlossen werden, bei der eine Behandlung der Varroatose durchgeführt werden sollte. Wenn dagegen keine Milbe gefunden wird, oder die gefundene Anzahl zwischen 0 und 6 liegt, kann die Populationsdichte niedriger als 0,05 bzw zwischen 0,05 und 0,1 weibliche Milben pro Zelle klassifiziert werden, was dann unterhalb der vorher festgelegten Interventionsschwelle wäre. In diesen letzten zwei Fällen könnte die Probennahme entweder bis zur Erfassung einer größeren Anzahl von Zellen fortgesetzt werden oder nach einigen Wochen wiederholt werden. Bei Verwendung der 
hier beschriebenen Technik brauchen bei minimalem Zeitaufwand nur wenige Proben genommen werden. Es ist aber notwendig, weitere Untersuchungen durchzuführen, um genauere Befallsdichten für die Interventionslevel festzulegen, ab denen mit deutlichen Schäden an den Bienenvölkern zu rechnen ist.

\section{Varroa jacobsoni / Dispersionsindex / räumliche Verteilung / sequentielle Pro- bennahme / verdeckelte Arbeiterinnen- brut / Apis mellifera ligustica}

\section{REFERENCES}

Ferrer-Dufol M, Moreno-Manera C, MartinezViñuales AI, Sánchez-Acedo C, Gracia-Salinas MJ (1995) Field trials of treatments against Varroa jacobsoni using fluvalinate and flumethrin strips in honey bee colonies containing sealed brood. J Apic Res 34, 3, 147-152

Floris I (1991) Dispersion indices and sampling plans for the honeybee (Apis mellifera ligustica Spin) mite Varroa jacobsoni Oud. Apicoltura, 7, 161-170

Floris I ( 1992) Ossevazioni sull'infestazione da Varroa jacobsoni Oud di covata femminile opercolata di Apis mellifera ligustica Spin.
Convegno "Stato attuale e sviluppo della ricerca in apicoltura », Sassari, Italy, 25-26 ottobre 1991, Atti, 87-98

Fuchs S (1988) The distribution of Varroa jacobsoni Oud on honeybee brood combs and within brood cells as a consequence of fluctuation infestation rates. In: European research on varroatosis control, Proc Meet EC Expert's Group, Bad Homburg 1986, $R$ Cavalloro Ed, Balkema, Rotterdam, The Netherlands 73-76

Iwao S (1968) A new regression method for analyzing the aggregation pattern of animal populations. Res Popul Ecol 10, 1-20

Iwao $S$ (1975) A new method of sequential sampling to classify populations relative to a critical density. Res Popul Ecol 16, 281-288

Iwao $\mathrm{S}$ (1977) The $\mathrm{m}^{*}$-m statistics as a comprehensive method for analyzing spatial patterns of biological populations and its application to sampling problems. In: Studies on methods of estimating population density, biomass and productivity in terrestrial animals edited by $M$ Morosita, reprinted from JIBP SYNTHESIS, Tokyo, Japan, 1977: 21-46

Milani N (1993) Analytical bibliography on Varroa jacobsoni Oud and related species. Apicoltura (Appendice), 8, $147 \mathrm{p}$

Southwood TRE (1978) Ecological methods. Champman and Hall, London, UK, 7-69

Taylor LR (1961) Aggregation, variance, and the mean. Nature 189, 732-735 